\title{
14 Responsibility for Fundamentalist Belief
}

\author{
Rik Peels
}

\section{Introduction}

The ethics of belief is nowadays a flourishing field at the intersection of ethics and epistemology. In this chapter, I apply various ideas from the current ethics of belief literature to an important phenomenon in our society: fundamentalism. Fundamentalism is one of those cases in which belief formation or belief maintenance is much like we do not want it to be. I do not have enough space in this short chapter to develop a full-blown ethics and epistemology of fundamentalist belief, which is, after all, a largely novel field for philosophers. What I would rather like to do is show how an ethics and epistemology of fundamentalist belief are relevant to current models in fundamentalism studies that aim to understand and explain fundamentalism, sketch the main issues that such an ethics and epistemology of fundamentalist belief would have to cover, and make various positive suggestions about what my own preferred approach, the so-called Influence View, would imply for the ethics and epistemology of fundamentalist belief.

The chapter is structured as follows. In $\$ 2$, I sketch the state-of-the-art in fundamentalism studies. Most importantly, I explain how the main models of the field—such as the pathology model and the radicalization model—fail for two reasons: they cannot explain why some people turn to fundamentalism while others do not and they cannot do justice to the fact that we often hold fundamentalists responsible for fundamentalist actions and beliefs. I explain how a philosophical model that provides an ethics and epistemology of fundamentalist belief can help the field to overcome these two problems. After that, I sketch which issues such a model would have to address. First, what is needed is an account of fundamentalist belief $(\$ 3)$ : what is it to hold a fundamentalist belief? Second, we need a theory of what is wrong with fundamentalist belief $(\$ 4)$ : is it moral wrongness, epistemic wrongness, or both? Third, even if fundamentalists in coming to hold or in maintaining certain fundamentalist beliefs violated certain obligations pertaining to their beliefs, it does not follow that they are culpable or blameworthy for that $(\$ 5)$. Whether or not they are, depends on whether they are properly excused for violating such obligations and for holding such beliefs. What we also need, then, is an account of excuses for fundamentalist beliefs. I conclude by exploring where we can go from here. 


\section{Background: The Stagnating Field of Fundamentalism Studies}

Fundamentalism is an important, harmful phenomenon in contemporary society. It is harmful in a wide variety of ways. Fundamentalist groups avoid contact with what they consider evil, modern, and, in the case of religious fundamentalisms, secular developments. They treat certain texts as infallible, they are suspicious of various kinds of science, they deny the distinction between public and private, and sometimes commit terrorist attacks. ${ }^{1}$ Fundamentalism impedes access to education for members of fundamentalist groups. ${ }^{2}$ It limits the rights of minorities like members of the LGBT community ${ }^{3}$ and people from different faiths or races. ${ }^{4}$ It negatively influences the public image of religions, especially Islam, and it is sometimes taken to display a clash of civilizations. ${ }^{5}$ Such fundamentalism can, but need not, be religious; there are all sorts of secular extreme ideologies that qualify as varieties of fundamentalism-e.g., certain kinds of neo-Nazism, left-wing political extremism, certain kinds of communism, versions of nationalism, and so on. ${ }^{6}$ Moreover, according to a number of scholars, fundamentalism is on the rise. ${ }^{7}$ It is, therefore, not merely harmful but increasingly so.

Since fundamentalism is so harmful, it is not surprising that there has been a lot of academic research on it. The field of fundamentalism studies is a research area at the intersection of sociology, religious studies, theology, law, psychiatry, history, criminology, and psychology that has over the last few decades been studying different kinds of fundamentalism and various types of expressions of fundamentalism. However, scholarly attention has almost entirely focused on fundamentalist behaviour rather than beliefs. That is not all that surprising either. After all, it is the actions (and omissions) that are primarily harmful, such as maltreating minorities, biased treatment of people from other faiths, terrorist attacks, lack of scientific education, and so on. This focus on behaviour has naturally led to historical and empirical research on fundamentalism. For instance, the seminal five-volume series The Fundamentalism Project, edited by Martin Marty and Scott Appleby, ${ }^{8}$ asks such questions as how different fundamentalisms in religions arise and when they lead to violence.

The main models used to explain why and predict when people display fundamentalist behaviour do not treat fundamentalists as rational and responsible individuals. Here are two examples. The so-called Radicalization Model explains the turn to fundamentalist behaviour by appeal to a process of radicalization that involves various social and political factors, such as poverty and social isolation. ${ }^{9}$ Increasingly, though, scholars from fundamentalism studies are dissatisfied with this model, since it is often unable to explain why one individual turns to fundamentalism while another in similar conditions does not. ${ }^{10}$ Another model explains the turn to fundamentalist action in terms of personality pathology. Let us call this the Pathology Model. This is equally problematic, because there is good evidence to think that most fundamentalists are fairly normal people and do not suffer from psychiatric disorders. Some people in the field of fundamentalism studies still claim that terrorists and other fundamentalists suffer from some sort of mental disorder, ${ }^{11}$ but the majority 
view nowadays is that we should consider fundamentalists as non-pathological people who act and think at least in some sense rationally. ${ }^{12}$ Since the main models in the field fail to explain and predict fundamentalist behaviour, an increasing number of fundamentalism experts claim that research in this field has stagnated for the past dozen years. ${ }^{13}$

There is an additional problem with these models that has not received that much attention. If fundamentalism is explained in terms of pathological traits or in terms of social and economic forces, that, as such, does not explain how fundamentalists can be responsible for their fundamentalist actions and omissions. In fact, if fundamentalism is entirely explained in terms of pathology and social and economic factors, one might wonder how fundamentalists could ever be responsible for their fundamentalism. However, we clearly $d o$ hold fundamentalists (at least in many cases) responsible for their behaviour. We need models that do justice to this.

These two problems-the failure to truly explain fundamentalism and the failure to do justice to the fact that most fundamentalists are responsible for their fundamentalism-jointly call for a new model. I think such a model can be developed by studying how fundamentalists can be responsible for fundamentalist beliefs. After all, many fundamentalists act from sincere beliefs that they are doing the right thing, and the fundamentalism literature has come to acknowledge that fundamentalist beliefs are often in some sense rational. ${ }^{14}$ Not all fundamentalists hold such beliefs-some simply follow an authoritative leader or someone they admire-but those leading figures themselves are usually rather convinced of various ideas that lead them to fundamentalism. Now, the ethics of belief literature has extensively studied how people can be responsible for their beliefs, what obligations they have regarding their beliefs, when and how people are excused for holding certain beliefs, and so on. Moreover, over the last few decades social epistemology has developed various tools for better understanding an individual's beliefs in relation to those of the group(s) she belongs to and those of the group(s) she does not belong to. What I have in mind here are various theories and arguments concerning group belief, group justification, collective ignorance, disagreement, and testimony.

My suggestion is, therefore, that, in order to get a firmer grip on fundamentalism and be better able to normatively assess it, we need an epistemology and ethics of fundamentalism. More specifically, we need to better understand what makes these beliefs fundamentalist, how an individual's fundamentalist beliefs relate to those of the group he or she belongs to, what duties fundamentalists have regarding their beliefs, and when they are excused for violating them. This provides a more fine-grained normative-theoretical framework for understanding and assessing fundamentalism in all its facets. An epistemology of fundamentalist belief will tell us what fundamentalist belief is and how the individual's fundamentalist beliefs relate to those of the fundamentalist group. An ethics of fundamentalist belief will tell us when we can properly praise, blame, or neutrally appraise fundamentalists for their beliefs ${ }^{15}$ by giving an account of which epistemic and moral obligations regarding their beliefs fundamentalists violate and when they are properly excused for doing 


\section{Rik Peels}

so. A full-blown epistemology and ethics of fundamentalist belief will also lay out exactly how fundamentalist belief relates to fundamentalist action. Such a theory is exactly what the field of fundamentalism studies needs.

\section{What is a Fundamentalist Belief?}

The literature on fundamentalism provides detailed historical and empirical work on which beliefs fundamentalists hold. The influential five-volume series The Fundamentalism Project (1991-1995) starts with a volume that also explores fundamentalist beliefs in various religions and worldviews. ${ }^{16}$ A large number of studies have followed, both on factual and normative fundamentalist beliefs. ${ }^{17}$ Moreover, various scales with a variety of psychometric properties have been developed to measure the degree of someone's religious fundamentalism. ${ }^{18}$ However, a rigorous conceptual and epistemological analysis of the nature of fundamentalist belief is absent in the literature: should we think of them in terms of content, degree of certainty, centrality to one's belief system, or various other properties, such as that of being self-enforcing? ${ }^{19}$ Philosophy can contribute to the field of fundamentalism studies here, both by studying which beliefs of the fundamentalist should count as fundamentalist beliefs and by conceptualizing the notion of fundamentalist belief that would play such a crucial role in an alternative model meant to understand and explain fundamentalism.

Conceptualizing fundamentalist belief is a large-scale project. Here I would like to make one important point: something cannot count as a fundamentalist belief merely in virtue of its propositional content. This is important, for it is prima facie plausible to define 'fundamentalist belief' with reference to its content, since fundamentalism as a movement is often defined in terms of such stereotypical properties as treating certain texts as infallible, being sceptical of certain kinds of science, treating women as inferior, biased treatment of people from different faiths and races, unequal treatment of members of the LGBT community, embracing a narrative about the world in terms of a paradise, fall, and redemption, and so on. One might, therefore, be tempted to spell out fundamentalist beliefs in corresponding terms: the belief that women have fewer rights than men, the belief that, say, the Qur'an or Genesis read literally is infallible, and so on.

This, however, will not do for at least two reasons. First, the account of fundamentalism in terms of the properties just given is widely taken to be an account in terms of stereotypical properties. Fundamentalism is usually understood in terms of a family resemblance. Thus, something is a case of fundamentalism if it exemplifies enough of the stereotypical properties just mentioned. This means that satisfying, say, just one or two of them will not do. Thus, if one embraces a couple of beliefs along the lines just mentioned but rejects most of them, one is not a fundamentalist. Fundamentalist content, so to say, of a belief therefore cannot all by itself be sufficient for some belief to be a fundamentalist belief.

Second, imagine that someone believes that science ought to be treated with great scepticism. However, she does not believe this because of 
narrow-mindedness, commitment to a religious system that seems to conflict with science, or any such thing. Rather, she believes this on the basis of an indepth investigation of the track-record of science. The investigation is far from perfect, but it is the best she can possibly do. Would her belief count as a fundamentalist belief? It seems it would not. In fact, this is an important position among anti-realists in the philosophy of science and the debate is still going on. Now, imagine she paradoxically also believes that women are inferior to men in important ways-again, on the basis of thorough (even though misguided) empirical inquiry. Would her belief count as fundamentalist? Surely not. Just to be clear: that belief of hers would be false. But she has done the very best she could in inquiring into these issues and she has done so open-mindedly. What this strongly suggests is that beliefs are fundamentalist beliefs only if they come about in a certain way and if they have certain problematic sources.

If beliefs are fundamentalist not merely in virtue of their content, what does turn beliefs into fundamentalist beliefs? Here is a hypothesis: fundamentalist beliefs are beliefs with a particular content that have not been formed in the right sort of way. Here are at least two ways this might be fleshed out. First, one might think that fundamentalist beliefs are a specific kind of extreme beliefs that violate norms of moderation in belief formation. Thoughts along these lines can be found in medieval Islamic philosophy. ${ }^{20}$ Second, one might think that fundamentalist beliefs are always beliefs that are brought about by the operation of intellectual vices. The epistemology of intellectual virtues and vices has been flourishing over the last two decades. I take intellectual virtues, such as open-mindedness and thoroughness,$^{21}$ to be intellectual character traits that enhance effective and responsible inquiry. Intellectual vices are their opposites: intellectual character traits that impede effective and responsible inquiry. ${ }^{22}$ Among the many intellectual vices are carelessness, closed-mindedness, conformity, cowardice, dogmatism, gullibility, idleness, insensitivity to detail, intellectual pride, lack of thoroughness, negligence, obtuseness, prejudice, rigidity, and wishful thinking. ${ }^{23}$

Note that it does not follow from this hypothesis that fundamentalist beliefs are beliefs for which one is necessarily blameworthy. This is because fundamentalist beliefs are beliefs for which one can be excused, say, by indoctrination. Thus, even though the belief formation would always be misguidedeither because it results from the violation of certain intellectual or epistemic obligations, or because it necessarily involves the activation of certain intellectual vices-and in that sense wrong, the fundamentalist would not always be blameworthy. I take this to be an advantage of this view: it does justice to the fact that, when people form fundamentalist beliefs, something goes wrong epistemically and often, but not always, the cognitive subjects involved are blameworthy.

Let me stress that both conditions are not only jointly sufficient, but that they are also individually necessary. All of us, imperfect people, form beliefs as the result of the violation of certain epistemic norms and as a result of the exercise of intellectual vices, but that does not render those beliefs fundamentalist. Not even all of the fundamentalist's beliefs issuing from the violation of 


\section{Rik Peels}

epistemic norms or the exercise of intellectual vices count as fundamentalistif a fundamentalist sloppily reads the newspaper and comes to believe that the Germans won the World Cup in soccer as a result, that belief is blameworthy, but it is not a fundamentalist belief. Not even if, in fact, the Dutch won it. What also seems required, then, is that the propositional content of the belief in question is constitutional of the fundamentalism in question or is relevantly related to it. Thus, a belief is fundamentalist only if it has such contents as that women are inferior to men or that science regarding the origin of the cosmos ought to be treated with scepticism, and relevantly related beliefs, such as the belief that this person (a girl) should not have the same education as boys, or the belief that contact with that person should be avoided, because she works in the biology department where evolutionary theory reigns.

Before we turn to the normative dimension of fundamentalist belief, let me say one more thing. So far, I have focused entirely on beliefs on individuals. However, ever since the rise of social epistemology, ${ }^{24}$ it has become customary to also consider whether groups, such as courts, boards, governments, and research groups can hold beliefs, be epistemically justified in believing something, be ignorant of something, or know something. ${ }^{25}$ If this is right-and it seems to me that it is-it would be only natural for one to ask what it is for a group to hold a fundamentalist belief. If what I argued above is correct, then it cannot merely be explained in terms of standard analyses of group belief plus a qualifier about fundamentalist content; one should also consider the ways in which those beliefs came about. But how is this supposed to work in the case of a group? Moreover, it is widely acknowledged in fundamentalism studies that the group conditions heavily influence the beliefs of the individual that belongs to it. ${ }^{26}$ Finally, fundamentalist beliefs of individuals are often based on the authority of and trust in others in the group. ${ }^{27}$ Clearly, much more rigorous philosophical work is needed. In what follows, I confine myself to fundamentalist beliefs of individuals.

\section{The Wrongness of Fundamentalist Beliefs}

Exactly what obligations do fundamentalists violate in acquiring or maintaining fundamentalist beliefs?

The ethics of belief literature displays a wide variety of norms pertaining to our beliefs, including the obligation to avoid false belief, the obligation to believe only truth, the duty to believe in accordance with one's evidence, the obligation to gather sufficient evidence, the duty to hold only rational beliefs, and so on. This chapter focuses on responsibility for fundamentalist beliefs, so I will confine myself to full-blown deontological obligations: obligations that are such that if one violates them without being excused, one is thereby blameworthy or culpable.

This leaves us with two metaphysically different kinds of obligations that are relevant to doxastic responsibility. On the one hand, some philosophers have argued that there are doxastic norms, rules, obligations, or duties. These are duties to hold or not to hold specific beliefs. Among the philosophers who 
have fleshed out such obligations some believe that we have them in virtue of our volitional or voluntary or intentional control over our beliefs. Others have argued, in response to William Alston's famous argument from doxastic involuntarism against the deontological conception of justification, ${ }^{28}$ that we lack voluntary control over our beliefs. Instead, they surmise, we have doxastic obligations because we have compatibilist control over our beliefs. ${ }^{29}$ This is spelled out differently by different philosophers, but a common account is one in terms of beliefs that are sufficiently reason-responsive.

On the other hand, there are philosophers who believe that we lack volitional control over our beliefs and that compatibilist control over our beliefs does not render us responsible for them. They suggest that we are derivatively responsible for our beliefs: we are responsible for our beliefs because we control various actions that make a difference to what we believe. We lack control over our beliefs, but we do have influence on them. Anthony Booth, Sanford Goldberg, Anne Meylan, Nikolaj Nottelmann, I myself, ${ }^{30}$ and others have defended an Influence View along these lines. The Influence View says that we generally lack doxastic obligations (there may be a few exceptional scenarios ${ }^{31}$ ), but we $d o$ have intellectual obligations, that is, obligations to perform belief-influencing actions. We are responsible-blameworthy, praiseworthy, neutrally appraisable-for our beliefs, because we bear derivative responsibility for our beliefs.

Since I have defended the Influence View in detail elsewhere, I will not repeat my criticisms of doxastic compatibilism here..$^{32}$ Rather, I will explore what responsibility for fundamentalist belief looks like on the Influence View. What I would like to suggest is that on the Influence View, the fundamentalist will generally violate both moral and epistemic intellectual obligations. Remember, intellectual obligations are obligations to perform belief-influencing actions or not to perform such actions. We have them in virtue of being human beings rather than in virtue of such contingent facts as specific tasks, commitments, and jobs (thus, the police have an obligation to investigate the murder, I have an obligation to check the train timetable if I promised to do so, and so on). Here is what I wrote on an earlier occasion about the moral intellectual obligations that we have:

A question that many philosophers will be interested in is whether there are any non-contingent intellectual obligations, obligations that we have, not in virtue of a voluntary commitment of some sort, but simply in virtue of being human. I think we do. For instance, Julia has a non-contingent moral intellectual obligation not to spy on her niece, for it is morally bad to acquire knowledge about such private matters and morally wrong (at least prima facie) to do so intentionally. If Julia violates this intellectual obligation, the moral badness involved is at least partly constituted by Julia's having certain knowledge (which entails certain beliefs) about her niece's private life that she should not have had. ${ }^{33}$

Do fundamentalists violate moral intellectual obligations? Well, if so, they will not be obligations like the obligation not to spy on your niece. After all, 


\section{Rik Peels}

violating such obligations leads to knowledge, true belief, justified belief, and beliefs with all sorts of other positive epistemic statuses. The moral wrongness in those cases of privacy violation is that of having access to and knowing certain things about another person that one should not know.

Someone might object that only the spying is morally wrong in this case; not so much having certain kinds of knowledge as a result of such spying. After all, there is nothing morally wrong about the knowledge as such: if Julia's niece freely shares her knowledge of her love affairs with Julia, there is nothing wrong with Julia's knowing these things. I agree that, in a situation like that, there is nothing morally wrong with Julia's knowing these things. It does not follow that there is nothing wrong with Julia's knowing these things once she finds them out by way of spying. Julia's niece, for instance, could rightly feel Julia has wronged her not merely by spying on her but also by coming to know certain things as a result of that. She may rightly think a situation in which Julia successfully spies—because it leads to knowledge-is even worse than a situation in which Julia unsuccessfully spies. She may feel wronged not only because of the intrusive act, but also by the very fact that Julia now knows something about her that she should not know. Apparently, things can be contingently wrong; not wrong if one freely brings it about, but wrong if the other person brings it about by way of the violation of an obligation.

Now, what about fundamentalist belief? Is fundamentalist belief a case of knowledge that came about in a wrong way? It seems not. With fundamentalist belief, things are crucially different: the relevant beliefs are widely considered to lack such positive statuses as being an instances of knowledge, being epistemically justified, being reliably formed, being true, and so on.

So, what is morally bad about these beliefs? I would like to suggest that there is not a single moral badness that they have in common. In fact, some may not be morally bad at all. Of course, to believe of homosexuals that they have fewer rights than heterosexuals is clearly morally wrong. It does not do justice to the rights that homosexuals have. To believe this about them wrongs them in some way. But it is not clear what the moral wrong is in believing that the world was literally created in six days some 6,000 years ago. Just to be clear: that belief is false and it seems epistemically wrong in a variety of ways. But it is not clear what is morally wrong with it (unless epistemic badness is a variety of moral badness, as Linda Zagzebski has suggested ${ }^{34}$ ).

What moral intellectual obligations do fundamentalists violate in coming to believe, say, that homosexuals have or should have fewer rights than heterosexuals or that women do not deserve the same sort of education that men deserve? Remember, if the Influence View is right, people do not really have a moral obligation to not believe these things. After all, they lack the sort of voluntary control over believing these things that having an obligation to not believe these things would require. Rather, they have an obligation (not) to perform various belief-influencing actions that make a difference to whether or not they believe these things. What such a belief-influencing action or various belief-influencing actions will look like may well differ from person to person: becoming more open-minded, reconsidering the evidence, talking to other 
people, and so on. These obligations are context-specific in that they depend on the particular wrong brought about by holding these fundamentalist beliefs. And, yet, these are also non-contingent or universal in the sense that they do not depend on any such contingent factors as having a particular role, job, task, or some such thing. The fundamentalist believer has these obligations simply in virtue of being a human being.

Now, could we say something similar about epistemic intellectual obligations and epistemic badness? If so, we would say something like this: in case a fundamentalist belief is epistemically wrong-it is false, it is unreliably formed, it is not in accordance with the evidence, or some such thing-one has an epistemic obligation to do one of those things that will rid one of the belief. The problem with this line of thinking is that it would give rise to way too many intellectual obligations. After all, we hold countless false beliefs, often where we have no clue to those beliefs being false. If the suggestion under consideration is correct, we would have numerous epistemic obligations to rid ourselves of all those false beliefs, unreliably formed beliefs, irrational beliefs, and so onobligations that we continually violate. That seems too strong a consequence.

So, what epistemic intellectual obligations do fundamentalists violate? Elsewhere, I have argued that we have a wide variety of subjective epistemic intellectual obligations. ${ }^{35}$ After all, we are not only sometimes blameworthy for doing that which is bad, but also for doing that which from our perspective is bad, whether or not it actually is. All things equal, we should not do what we believe to be bad. I prefer to cash out such subjective obligations in terms of what one believes rather than in terms of what one should believe. Elsewhere, I have explained why:

Thus, the suggestion is that subjective epistemic obligations should be understood in terms of what one believes. I prefer this to understanding subjective obligations in terms of what one should believe. I cannot defend this preference in detail here, but I would like to give at least one reason to prefer the former over the latter approach. I argued that doxastic responsibility should be understood in terms of intellectual obligations. It follows that if one should believe that $p$ [but one fails to do so; RP], then one has violated an intellectual obligation at some earlier time. But if subjective obligations are understood in terms of what one should believe rather than in terms of what one believes, then it seems that the chain of intellectual obligations would be endless. This is because an intellectual obligation would have to be explained in terms of what one should have believed at some earlier time and that would have to be explained in terms of what one should have believed at an even earlier time, and so forth. ${ }^{36}$

What would be examples of the violation of such subjective epistemic intellectual obligations be? Here are some examples: (a) One believes that one should really talk to that other person, but one does not do so because one does not want to do so (say, one is jealous of that person's achievements). Since one fails 


\section{Rik Peels}

to talk to that other person, one lacks crucial evidence that one would have had if one had talked to that person and that would have made a difference to what one believes. (b) One believes that one should investigate the trustworthiness of this pastor in more detail before accepting his views, but one fails to do so, again, thereby failing to have important evidence. (c) One believes that two beliefs that one holds are in tension with each other, that they cannot both be true, and that one should therefore further explore the contents of and evidential basis for each of them, but one fails to do so. It seems that all of us violate such epistemic (the badness is primarily epistemic rather than moral or prudential) intellectual obligations. Note that the fundamentalist need not violate an epistemic intellectual obligation that is more or less causally directly related to a specific belief in order for her to be blameworthy for that belief. She can also violate, say, a subjective epistemic intellectual obligation to work on her intellectual vice of narrow-mindedness. If she fails to do so on several occasions and, years later, she forms a fundamentalist belief that she would not have formed if she had met her obligation (or maybe even several of them), she can be blameworthy for that.

What if the fundamentalist does not violate any subjective epistemic intellectual obligations at all? This is hard to imagine. A scenario like that would look as follows. She believes it is perfectly fine not to listen to others, she believes it is fine to trust a source that, upon some further reflection, is clearly corrupt, she believes it is alright to disagree with the majority without any kind of argument, and so on. Such a fundamentalist is what we could call a second-order fundamentalist: she not only holds a wide variety of fundamentalist beliefs, but—on a second order-also believes it is perfectly fine to believe these things and believes that in coming to believe these things she did not violate any obligation whatsoever: at every point in coming to acquire these beliefs, she thought it was alright or even good to acquire those beliefs.

In assessing a scenario like this, we run into the debate about the so-called Origination Thesis, as defended by, for instance, Michael Zimmerman. ${ }^{37}$ The core idea of that thesis is that if someone is blameworthy for something, then she has at least at some point in time acted against her better judgment (akrasia). Elsewhere, I have fine-tuned that thesis: one can also be blameworthy if one acted from dormant and tacit beliefs (that would not count as akrasia) and in some cases if one acted even though one suspended judgment on, say, whether that was the right thing to do. I believe, though, that the basic idea of the Origination Thesis is true: one is blameworthy and the fundamentalist is blameworthy for acting as she does or believing something only if at some point her doxastic attitudes about her factual and normative situation did not match what she did. In other words, at some point, she acted against her beliefs, disbeliefs, and suspensions on what the right thing to do was. After all, it is hard to see how one could be blameworthy if one always acted in accordance with what one believed was the right thing. I will not delve into the debate about the Origination Thesis again here. Rather, let me point out that it levels an interesting hypothesis for the field of fundamentalism studies, a hypothesis that deserves further, rigorous empirical 
scrutiny. The hypothesis would be that the fundamentalist is blameworthy for holding certain fundamentalist beliefs and for acting on those beliefs only if in coming to hold those beliefs or forming those beliefs, she violated certain subjective intellectual obligations without any proper excuse for doing so, for instance by acting against her beliefs about what was the right thing to do. Investigating a thesis along these lines will not be easy. On the contrary, a fundamentalist is a fundamentalist and will, thus, normally believe that in believing the things she believes, she believes the right thing. Also believing that one violated various intellectual obligations in coming to hold those beliefs would, for a rational person, undermine holding those beliefs. Thus, it is unlikely that the fundamentalist will present such cases of violating intellectual obligations. Yet, it would be worthwhile to investigate her mental states or what she recalls about them at various stages that were crucial in coming to form and maintain the fundamentalist beliefs that she holds. After all, we might have good reasons to interpret some cases as cases of violating subjective epistemic intellectual obligations, even though the fundamentalist in her interpretation of those cases sees them in a different light (yet her presentation of them might give us enough reason to differ from her in our interpretation of them).

All this is not to deny that fundamentalist believers may also violate epistemic or professional or moral intellectual obligations regarding their beliefs that arise from such contingent factors as tasks, jobs, promises, and so on. That some intellectual obligations arise from these is often acknowledged in the literature ${ }^{38}$ and fundamentalist belief seems no different. Thus, a highschool teacher in biology may have an additional professional obligation to work on her beliefs regarding evolution and creation. All I have wanted to suggest here, though, is that even in the absence of such specific roles and tasks fundamentalists violate intellectual obligations, both moral and epistemic, that they have simply in virtue of being human beings.

\section{Excuses for Fundamentalist Belief}

It is one thing to violate an obligation with regard to one's beliefs, fundamentalist beliefs included. It is quite another thing to be blameworthy for the violation of such obligations. What bridges the gap is not being excused: one is blameworthy for violating an obligation only if one is not excused for doing so. ${ }^{39}$ Since it is widely taken that fundamentalists are often blameworthy for their beliefs, ${ }^{40}$ a viable ethics of fundamentalist belief should be able to explain when someone is excused for fundamentalist beliefs and when he or she is not.

Ethicists have studied the nature of excuses ${ }^{41}$ and various problems regarding excuses, such as whether moral ignorance can excuse. ${ }^{42}$ Ethicists have also paid considerable attention to specific excuses, such as the inability to act otherwise ${ }^{43}$ and ignorance. ${ }^{44}$ However, the focus has been on excuses for actions, not so much on excuses for beliefs. There have been a few studies on excuses for belief ${ }^{45}$ and one on indoctrination in particular, ${ }^{46}$ but these are exceptional. Moreover, what needs to be done is that this work should be taken 


\section{Rik Peels}

a step further by exploring when people are excused for violating obligations regarding fundamentalist beliefs.

From a more empirical perspective, we $d o$ find a large number of studies on excuses for belief, especially the excuses of brainwashing and indoctrination, or, as some scholars prefer to phrase it, "thought reform" or "thought persuasion" ${ }^{47}$ However, this work focuses on the context-specific social and political factors, rather than building an ethical theory of when specific excuses hold for fundamentalist beliefs. What fundamentalism studies as a field needs, in order to better understand and assess fundamentalism in all its facets, is a thorough analysis of (1) the various excuses that can hold with respect to fundamentalist beliefs, (2) how they relate to the obligations that fundamentalists are subject to, and (3) when excuses hold on an individual level and when they hold on a group level, as well as (4) a carefully developed theory that provides criteria for distinguishing which excuses fully or partially hold in specific circumstances.

The legal theorists and philosophers of law have also paid considerable attention to excuses for action and also for belief. ${ }^{48}$ Even though an ethics and epistemology can profit from the ideas covered in the philosophy of law, the existing work as such will not do. The reason for that is that the law does not merely work with what one is responsible for, but also the societal effects of (not) punishing someone, whether there has been a precedent or not, the likelihood of it happening again if someone is punished, and so on. Epistemology and ethics, however, focus on exactly which beliefs a person holds and whether that person is epistemically and morally responsible for those fundamentalist beliefs.

Now, one might of course explore the general doxastic excuses for fundamentalist belief, such as ignorance ${ }^{49}$ However, a substantial ethics of belief will also have to pay special attention to specific doxastic excuses that seem to occur more often in the case of fundamentalist belief than elsewhere. What I have in mind are such doxastic excuses as manipulation, cultural difference, peer pressure, social isolation, and indoctrination..$^{50}$

We should note that whether or not one of these factors excuses a person depends on whether or not she was in any way responsible for them. Indoctrination, for example, may excuse, but whether it does so depends on whether or not one was culpable for being indoctrinated. One might think, for instance, that an ISIS fighter voluntarily leaving the United Kingdom and ending up being indoctrinated in Syrian ISIS territory may be indoctrinated but not excused because she could and should have avoided being subject to such indoctrination. Or someone growing up in ISIS territory may go through a period of intense indoctrination but we might think that after she has lived in Germany for more than 20 years, she could and should have been able to rid herself of the most harmful effects of that indoctrination -it is at least not a full excuse for her fundamentalist beliefs (that is, that she is at least blameworthy to some degree for them). This means that there inevitably is an historical or, to use another term, diachronic dimension to these excuses; in order to know whether a certain state of affairs excuses a person, we need to know whether one was responsible for the actualization of that state of affairs in the first place. This squares well with the main tenets of the Influence View: we need to 
understand responsibility for beliefs not in terms of the reason-responsiveness of one's beliefs or at least not merely in those terms, but also at least partly in terms of the actions and omissions that in the course of time led to those beliefs.

Of course, unless the fundamentalist changes her mind and gives up various fundamentalist beliefs, she will normally not present various states of affairs as excusing circumstances. Yet, her description of those states of affairs might lead $u s$ to conclude that certain excusing circumstances obtain.

\section{Conclusion}

Let me draw the threads of this chapter together. I have argued that the current state of the art in fundamentalism studies is, to use a euphemism, sub-optional and that philosophers-ethicists and epistemologists in particular-can play an important role in helping us to understand why people make the turn towards fundamentalism. The main empirical models lack explanatory power and cannot do justice to the fact that most fundamentalists are responsible for what they believe and do. What is needed, then, is a philosophical model, based on thorough empirical inquiry, that can explain how normal, often rational people can make the turn to fundamentalism and how they are still responsible for doing so. Among other things, such a model will conceptually explore the nature of fundamentalist beliefs, study the relation between the beliefs of the individual fundamentalist and those of the group that he or she belongs to, lay out various contingent and necessary moral and epistemic obligations that fundamentalists violate, and spell out under which conditions fundamentalists are excused for doing so. ${ }^{51}$

\section{Notes}

1 See Marty and Appleby 1991a, 1991b; Ruthven 2004; Shupe 2011.

2 See Beyerlein 2004; West 2016.

3 See Cunningham and Melton 2013.

4 See Rose and Firmin 2016.

5 See Oudenampsen 2016.

6 See Hardin 2002.

7 Thus, Emerson and Hartman 2006.

8 Marty and Appleby 1991-1995.

9 HM Government 2009; Sageman 2016.

10 Cassam 2018; Sageman 2014; 2016.

11 E.g. Lankford 2013.

12 See Baurman 2007; Cassam 2018; Crenshaw 2011; Horgan 2005; Sageman 2004; 2014; 2016. In what follows, I am particularly inspired by the writings of Michael Baurman and Quassim Cassam.

13 E.g., Sageman 2014; 2016.

14 E.g., Baurman 2007; Cassam 2018; Sageman 2014.

15 For an account of responsibility in terms of such reactive attitudes as praise and blame, see Strawson 1974.

16 Mark and Appleby 1991. 


\section{Rik Peels}

17 E.g., Friedman and Rholes 2007; Hardin 2002; Yelderman et al. 2018.

18 E.g., Altemeyer and Hunsberger 2004.

19 Hardin 2002.

20 See Booth 2016; Winter 2006.

21 For an early exploration of the intellectual virtues, see Zagzebski 1996.

22 Thus also Cassam 2016.

23 For more on these, see Baehr 2011; Battaly 2010, 2016; Cassam 2016; Fricker 2007.

24 See, for instance, Goldman and Blanchard 2016.

25 See Brady and Fricker 2016; Klausen 2015; Mathiesen 2006; Peels and Lagewaard 2021; Tuomela 1995.

26 Hardin 2002.

27 Altemeyer and Hunsberger 1992; Hardin 2002.

28 See Alston 1989.

29 E.g. McHugh 2014.

30 Booth 2014; Goldberg 2018; Meylan 2013; Nottelmann 2007; Peels 2017a.

31 For some of those, see Peels 2015.

32 For such criticism, see Peels 2014a, 2017a.

33 Peels 2017a, 101.

34 See Zagzebski 1996. Here, I will assume with most other epistemologists that her argument for the idea that all epistemic badness is reducible to moral badness is not convincing.

35 See Peels 2017a, ch. 3.

36 Peels 2017a, 104-105.

37 See, for instance, Zimmerman 2008.

38 Goldberg 2018; McCormick 2015; Peels 2017a.

39 See Zimmerman 1988, 1996, 2008.

40 See, for instance, Cassam 2018; Shupe 2011.

41 Brandt 1969.

42 Rivera-López 2006.

43 Fischer and Ravizza 1998.

44 Harman 2011; Rosen 2003, 2004; Smith 2011; Zimmerman 1986, 1997.

45 Van Woudenberg 2009.

46 Yaffe 2003.

47 Pratkanis and Aronson 2001; Tan 2011; Taylor 2004.

48 E.g., Ginsburg and Richardson 1998.

49 See, for instance, Peels 2014b; 2017a, ch. 5; Peels 2017b.

50 See Yaffe 2003.

51 I would like to thank Kevin McCain for his astute and helpful comments on an earlier version of this chapter. Work on this chapter was made possible by the project EXTREME (Extreme Beliefs: The Epistemology and Ethics of Fundamentalism), which has received funding from the European Research Council (ERC) under the European Union's Horizon 2020 research and innovation programme (Grant agreement No. 851613). I would like to thank Imane Amara for carefully proofreading this chapter.

\section{References}

Alston, William P. 1989. “The Deontological Conception of Epistemic Justification.” In Epistemic Justification: Essays in the Theory of Knowledge. Ithaca, NY: Cornell University Press, 115-152. 
Altemeyer, Bob, and Hunsberger, Bruce. 1992. "Authoritarianism, Religious Fundamentalism, Quest, and Prejudice." International Journal for the Psychology of Religion 2: 113-133.

Altemeyer, Bob, and Hunsberger, Bruce 2004. "A Revised Religious Fundamentalism Scale: The Short and Sweet of it." International Journal for the Psychology of Religion 14: 47-54.

Baehr, Jason. 2011. The Inquiring Mind: On Intellectual Virtues and Virtue Epistemology. New York: Oxford University Press.

Battaly, Heather D. 2010. "Epistemic Self-Indulgence.” In Heather D. Battaly (ed.), Virtue and Vice, Moral and Epistemic. Oxford: Routledge, 215-236.

Battaly, Heather D. 2016 "Epistemic Virtue and Vice: Reliabilism, Responsibilism, and Personalism." In Chienkuo Mi, Michael Slote and Ernest Sosa (eds), Moral and Intellectual Virtues in Western and Chinese Philosophy. New York: Routledge, 99-120.

Baurman, Michael. 2007. "Rational Fundamentalism? An Explanatory Model of Fundamentalist Beliefs.” Episteme 4 (2): 150-166.

Beyerlein, K. 2004. "Specifying the Impact of Conservative Protestantism on Educational Attainment.” Journal for the Scientific Study of Religion 43 (4): 505-518.

Booth, Anthony R. 2014. "On Some Recent Moves in Defense of Doxastic Compatibilism.” Synthese 191 (8): 1867-1880.

Booth, Anthony R. 2016. Islamic Philosophy and the Ethics of Belief. London: Palgrave Macmillan.

Brady, Michael S., and Fricker, Miranda. 2016. The Epistemic Life of Groups: Essays in the Epistemology of Collectives Oxford: Oxford University Press.

Brandt, Richard B. 1969. "A Utilitarian Theory of Excuses.” Philosophical Review 78 (3): 337-361.

Cassam, Quassim. 2016. "Vice Epistemology.” The Monist 99: 159-180.

Cassam, Quassim. 2018. "The Epistemology of Terrorism and Counterterrorism." Philosophy, Supplementary Volume: Harms and Wrongs in Epistemic Practice, draft paper.

Crenshaw, Martha. 2011. Explaining Terrorism: Causes, Processes, and Consequences. London: Routledge.

Cunningham, George B., and Melton, E. Nicole. 2013. "The Moderating Effects of Contact with Lesbian and Gay Friends on the Relationships among Religious Fundamentalism, Sexism, and Sexual Prejudice." Journal of Sex Research 50 (3-4): 401-408.

Emerson, Michael O., and Hartman, David. 2006. "The Rise of Religious Fundamentalism.” Annual Review of Sociology 32: 127-144.

Fischer, John M., and Ravizza, Mark. 1998. Responsibility and Control: A Theory of Moral Responsibility. Cambridge: Cambridge University Press.

Friedman, Mike, and Rholes, W. Steven. 2007. "Successfully Challenging Fundamentalist Beliefs Results in Increased Death Awareness.” Journal of Experimental Social Psychology 43 (5): 794-801.

Fricker, Miranda. 2007. Epistemic Injustice: Power and the Ethics of Knowing. Oxford: Oxford University Press.

Ginsburg, Gerald, and Richardson, James T. 1998. “ Brainwashing' Evidence In Light of Daubert.” In Helen Reece (ed.), Law and Science. Oxford: Oxford University Press, $265-288$.

Goldberg, Sanford C. 2018. To the Best of Our Knowledge: Social Expectations and Epistemic Normativity. Oxford: Oxford University Press. 


\section{Rik Peels}

Goldman, Alvin, and Blanchard, Thomas. 2016. "Social Epistemology.” In Edward N. Zalta (ed.), The Stanford Encyclopedia of Philosophy. https://plato.stanford.edu/ archives/win2016/entries/epistemology-social/.

Hardin, Russell. 2002. “The Crippled Epistemology of Extremism.” In Albert Breton et al. (eds), Political Extremism and Rationality. Cambridge: Cambridge University Press, 3-22.

Harman, Elizabeth. 2011. “Does Moral Ignorance Exculpate?” Ratio 24 (4): 443-468.

HM Government. 2009. Pursue Prevent Protect Prepare: The United Kingdom's Strategy for Countering International Terrorism, https://assets.publishing.service. gov.uk/government/uploads/system/uploads/attachmentdata/file/228907/7833.pdf.

Horgan, John. 2005. The Psychology of Terrorism. Abingdon, Oxon: Routledge.

Klausen, Søren. 2015. “Group Knowledge: A Real-World Approach.” Synthese 192 (3): 813-839.

Lankford, Adam. 2013. The Myth of Martyrdom: What Really Drives Suicide Bombers, Rampage Shooters, and Other Self-Destructive Killers. New York: Palgrave Macmillan.

Marty, Martin E., and Appleby, R. Scott. 1991a. "Introduction: The Fundamentalism Project: A User's Guide." In Martin E. Marty and R. Scott Appleby (eds), Fundamentalisms Observed. The Fundamentalism Project, vol. 1. Chicago, IL: University of Chicago Press, pp. vii-xiii.

Marty, Martin E., and Appleby, R. Scott (eds). 1991b. "Conclusion: An Interim Report on A Hypothetical Family.” In Martin E. Marty and R. Scott Appleby (eds), Fundamentalisms Observed. The Fundamentalism Project, vol. 1. Chicago, IL: University of Chicago Press, 814-842.

Marty, Martin E., and Appleby, R. Scott (eds). 1991-5. The Fundamentalism Project. 5 vols. Chicago, IL: University of Chicago Press.

Mathiesen, Kay. 2006. "The Epistemic Features of Group Belief." Episteme 2 (3): 161-175.

McCormick, Miriam S. 2015. Believing Against the Evidence: Agency and the Ethics of Belief. New York: Routledge.

McHugh, Conor. 2014. "Exercising Doxastic Freedom." Philosophy and Phenomenological Research 88 (1): 1-37.

Meylan, Anne. 2013. Foundations of an Ethics of Belief. Berlin: Walter de Gruyter.

Nottelmann, Nikolaj. 2007. Blameworthy Belief: A Study in Epistemic Deontologism. Dordrecht: Springer.

Oudenampsen, Merijn. 2016. "Deconstructing Ayaan Hirsi Ali: On Islamism, Neoconservatism, and the Clash of Civilizations." Politics, Religion, and Ideology 17 (2-3): 227-248.

Peels, Rik. 2014a. “Against Doxastic Compatibilism.” Philosophy and Phenomenological Research 89 (3): 679-702.

Peels, Rik. 2014b. "What Kind of Ignorance Excuses? Two Neglected Issues." Philosophical Quarterly 64 (256): 478-496.

Peels, Rik. 2015. “Believing at Will Is Possible.” Australasian Journal of Philosophy 93 (3): 524-541.

Peels, Rik. 2017a. Responsible Belief: A Theory in Ethics and Epistemology. New York: Oxford University Press.

Peels, Rik. 2017b. Perspectives on Ignorance from Moral and Social Philosophy. London: Routledge.

Peels, Rik, and Thirza Lagewaard. 2021. "Group Ignorance: An Account Based on Case Studies of Fundamentalist and White Ignorance." In Jennifer Lackey and 
Aidan McGlynn (eds), Oxford Handbook of Social Epistemology. Oxford: Oxford University Press, forthcoming.

Pratkanis, Anthony, and Aronson, Elliot. 2001. Age of Propaganda: The Everyday Use and Abuse of Persuasion. New York: Henry Holt.

Rivera-López, Eduardo. 2006. "Can There Be Full Excuses for Morally Wrong Actions?” Philosophy and Phenomenological Research 73 (1): 124-142.

Rose, Stephanie Firebaugh, and Firmin, Michael W. 2016. "Racism in Interracial Dating: A Case Study in Southern Culture and Fundamentalism." Christian Higher Education 15 (3): 140-152.

Rosen, Gideon. 2003. "Culpability and Ignorance." Proceedings of the Aristotelian Society 103 (1): 61-84.

Rosen, Gideon. 2004. "Skepticism about Moral Responsibility." In Philosophical Perspectives: Ethics, vol. 18, ed. John Hawthorne. Malden, MA: Blackwell Publishing, 295-311.

Ruthven, Malise. 2004. Fundamentalism: The Search for Meaning. Oxford: Oxford University Press.

Sageman, Marc. 2004. Understanding Terror Networks. Philadelphia, PA: University of Pennsylvania Press.

Sageman, Marc. 2014. "The Stagnation in Terrorism Research.” Terrorism and Political Violence 26 (4): 565-580.

Sageman, Marc. 2016. Misunderstanding Terrorism. Philadelphia, PA: University of Pennsylvania Press.

Shupe, Anson. 2011. “Religious Fundamentalism.” In Peter B. Clarke (ed.), The Oxford Handbook of the Sociology of Religion. Oxford: Oxford University Press, 478-490.

Smith, Holly M. 2011. "Non-Tracing Cases of Culpable Ignorance." Criminal Law and Philosophy 5 (2): 115-146.

Strawson, Peter F. 1974. "Freedom and Resentment." In Freedom and Resentment and Other Essays. London: Methuen, 1-25.

Tan, Charlene. 2011. Islamic Education and Indoctrination: The Case of Indonesia. London: Routledge.

Taylor, Kathleen. 2004. Brainwashing: The Science of Thought Control. Oxford: Oxford University Press.

Tuomela, Raimo. 1995. The Importance of Us: A Study of Basic Social Notions. Stanford, CA: Stanford University Press.

Van Woudenberg, René. 2009. "Ignorance and Force: Two Excusing Conditions for False Beliefs.” American Philosophical Quarterly 46 (4): 373-386.

West, Linden. 2016. Distress in the City: Racism, Fundamentalism, and a Democratic Education. London: Trentham Books.

Winter, Timothy J. 2006. "The Poverty of Fanaticism.” In Joseph E. B. Lumbard (ed.), Islam, Fundamentalism, and the Betrayal of Tradition: Essays by Western Muslim Scholars. Bloomington, IN: World Wisdom, 301-314.

Yaffe, Gideon. 2003. "Indoctrination, Coercion, and Freedom of the Will." Philosophy and Phenomenological Research 67 (2): 335-356.

Yelderman, Logan A., West, Matthew P., and Miller, Monica K. 2018. "Death Penalty Decision-Making: Fundamentalist Beliefs and the Evaluation of Aggravating and Mitigating Circumstances." Legal and Criminological Psychology, DOI: https://doiorg.vu-nl.idm.oclc.org/10.1111/lcrp.12141.

Zagzebski, Linda T. 1996. Virtues of the Mind: An Inquiry into the Nature of Virtue and the Ethical Foundations of Knowledge. Cambridge: Cambridge University Press. 


\section{Rik Peels}

Zimmerman, Michael J. 1986. "Negligence and Moral Responsibility.” Nô̂s 20 (2): 199-218.

Zimmerman, Michael J.1988. An Essay on Moral Responsibility. Totowa, NJ: Rowman \& Littlefield.

Zimmerman, Michael J. 1996. The Concept of Moral Obligation. Cambridge: Cambridge University Press.

Zimmerman, Michael J. 1997, “Moral Responsibility and Ignorance.” Ethics 107 (3): $410-426$.

Zimmerman, Michael J. 2008. Living with Uncertainty: The Moral Significance of Ignorance. Cambridge: Cambridge University Press. 